\title{
Phase II study of weekly paclitaxel and capecitabine in patients with metastatic or recurrent esophageal squamous cell carcinoma
}

\author{
Tak Yun ${ }^{1}$, Ji-Youn Han ${ }^{1}$, Jin Soo Lee ${ }^{1}$, Hyun Lee Choi ${ }^{1}$, Hyae Young Kim, Byung-Ho Nam² and Heung Tae Kim*
}

\begin{abstract}
Background: This phase II study assessed the response rate and toxicity profile of weekly paclitaxel and capecitabine in patients with metastatic or recurrent squamous cell carcinoma of the esophagus (SCCE)

Methods: Patients with histologically confirmed SCCE were treated with paclitaxel $80 \mathrm{mg} / \mathrm{m}^{2}$ intravenously on days 1 and 8 plus capecitabine $900 \mathrm{mg} / \mathrm{m}^{2}$ orally twice a day on days $1-14$. Treatment cycles were repeated every 3 weeks until disease progression or unacceptable toxicity.

Results: Between 2006 and 2009, 32 patients were enrolled. Twelve patients were chemotherapy-naïve. Twenty patients had received prior chemotherapy including platinum-based regimens. Patients received a median of 5 cycles of treatment (range, 1-12). The response rate was $75 \%(95 \% \mathrm{Cl} ; 50.5 \sim 99.5 \%)$ in the first-line and $45 \%(95 \% \mathrm{Cl}$; 26.9 73.1\%) in the second-line. With a median follow-up of 20.7 months, median progression-free survival was 5.2 months ( $95 \% \mathrm{Cl}, 4.0$ to 6.4) for all patients and median overall survival (OS) was 11.7 months (95\% Cl, 5.5 to 18.0) for all patients. The median OS was 14.3 months ( $95 \% \mathrm{Cl}, 10.6$ to 18.0$)$ for patients receiving therapy as $1^{\text {st }}$ line and 8.4 months $(95 \% \mathrm{Cl}, 6.6$ to 10.1$)$ for those receiving as $2^{\text {nd }}$-line therapy. Grade $3 / 4$ neutropenia was observed in $53.3 \%$ of the patients, which was the most common cause of dose reduction. G3 non-hematologic toxicity included stomatitis (9.4\%), asthenia (6.3\%), and hand-foot skin reaction (3.1\%).
\end{abstract}

Conclusions: Weekly paclitaxel and capecitabine is a highly active and well-tolerated regimen in patients with metastatic or recurrent SCCE in the first-line as well as second-line setting.

Keywords: paclitaxel, capecitabine, squamous cell carcinoma of the esophagus

\section{Background}

Esophageal cancer is characterized by poor prognosis, with $50 \%$ of patients presenting with metastatic disease at the time of diagnosis. In the remaining $50 \%$ of patients presenting initially with loco-regional disease, systemic metastatic disease will develop in the vast majority. The prognosis for patients diagnosed with advanced esophageal cancer is poor with a 5 -year survival of $10-15 \%$ from diagnosis [1]. Conventional single agents active in esophageal cancer include cisplatin, 5FU, etoposide, and mitomycin, with response rates ranging from $15 \%$ to $25 \%$ [1-4]. The two-drug combination of cisplatin and 5-FU has been the standard regimen for

\footnotetext{
* Correspondence: htkim@ncc.re.kr

'Lung Cancer Branch, National Cancer Center, Goyang, Republic of Korea Full list of author information is available at the end of the article
}

two decades, with a $25-35 \%$ response rate in metastatic disease. However, complete responses are rare, median duration of response is usually short, and the median survival time is only 6-10 months [5]. New regimens such as paclitaxel-cisplatin-5FU and irinotecan-cisplatin have shown promising anti-tumor activity in phase II trials $[2,6]$. Since first-line therapies are not curative, patients eventually experience disease progression. Once the disease progresses, the median survival time is very short. No regimen can be considered as standard in the second-line setting. Thus, patients with good performance status are candidates for clinical trials exploring further treatment options.

Paclitaxel is used at a dose range of 135 to $200 \mathrm{mg} / \mathrm{m}^{2}$ over 3 hours in patients with other solid tumors such as non-small cell lung cancer. However, toxicities have
C Biomed Central

(c) 2011 Yun et al; licensee BioMed Central Ltd. This is an Open Access article distributed under the terms of the Creative Commons Attribution License (http://creativecommons.org/licenses/by/2.0), which permits unrestricted use, distribution, and reproduction in any medium, provided the original work is properly cited. 
been excessive when combined with cisplatin. Weekly paclitaxel showed comparable efficacy to that of 3 weekly paclitaxel, while having a lower incidence of myelosuppression and neurotoxicity $[7,8]$.

Capecitabine is an orally administered fluoropyrimidine that is converted by 5 -FU by thymidine phosphorylase (TP), preferentially in tumor tissues and has demonstrated activity as single agent in patients with gastrointestinal cancers. The tumor selectivity of capecitabine has been documented in clinical studies, where administration of capecitabine has been shown to result in approximately 2.5 times higher concentrations of 5FU in the tumor tissue than in normal tissues [9]. Orally administered capecitabine mimics continuous-infusion of 5-FU, is well tolerated, with hand-foot syndrome and diarrhea the most common toxicities reported, and is more convenient for patients.

Taxanes upregulate the activity of TP in mouse mammary tumor cells in vitro and in xenograft models [10]. This taxane-mediated upregulation is synergistic, time dependent, and persists for up to 10 days. Thus, sequential administration of taxanes followed by capecitabine could result in enhanced efficacy of capecitabine. The different toxicity profiles of the two drugs and preclinical synergy provide the rationale for evaluating the combination of capecitabine with paclitaxel clinically. Also, taxanes plus capecitabine were reported to be highly active against non-small cell lung cancer [11], breast cancer [12], and gastric cancer [13]. Schedule optimization based on the upregulation of TP may result in a greater therapeutic index, thus allowing for the determination of the most advantageous way of combining these agents. In preclinical experiments, upregulation of TP activity was noted within 4 days of taxane treatment, and the effect was maximal at about 6-8 days [10]. Hence, a weekly schedule of paclitaxel would provide improved synergy for administration in combination with capecitabine. Considering synergistic activity and the different toxicity profiles of paclitaxel and capecitabine, we conducted a phase II trial evaluating the efficacy and safety in patients with esophageal squamous cell carcinoma.

\section{Methods}

\section{Study Population}

Patients with metastatic or recurrent squamous cell carcinoma of the esophagus that had been histologically confirmed were eligible. Additional inclusion criteria were as follows; 1 ) at least 18 years old, 2) ECOG performance status of 0 to 2,3 ) measurable lesions defined as RECIST 1.0,4) adequate bone marrow, hepatic, and renal functions, defined as $\mathrm{WBC} \geq 3,500 / \mathrm{mm}^{3}$, absolute neutrophil count $(\mathrm{ANC}) \geq 1,500 / \mathrm{mm}^{3}$, platelets $\geq$ $100,000 / \mathrm{mm}^{3}$, ALT or AST $<2.5$ times the upper normal limit, bilirubin $\leq 1.5$ times the upper normal limit, and serum creatinine $\leq 1.5 \mathrm{mg} / \mathrm{dL}, 5$ ) no prior radiotherapy to measurable lesions. Patients were excluded if there was severe co-morbidity such as myocardial infarction within preceding 6 months or symptomatic heart disease including unstable angina, congestive heart failure, or uncontrolled arrhythmia, and serious concomitant infection. Patients unable to swallow the capecitabine tablets were also excluded, even after placement of a stent.

Written informed consent approved by the Institutional Review Board of National Cancer Center was obtained from all patients prior to entering the study. The study followed the Declaration of Helsinki and good clinical practice guidelines. This study is registered with http://ClinicalTrials.gov (identifier; NCT00453323).

\section{Treatment}

Paclitaxel (Padexol ${ }^{\circledR}$ ) was provided by Shinpoong pharmaceutical company and capecitabine (Xeloda ${ }^{\circledR}$ ) was provided by Roche. Treatment was given in the outpatient setting. It consisted of paclitaxel $80 \mathrm{mg} / \mathrm{m}^{2}$ intravenously on days 1 and 8 and capecitabine $900 \mathrm{mg} / \mathrm{m}^{2}$ orally twice a day on days 1-14 followed by a 1 week rest period. The Treatment cycle was repeated every 3 weeks, until disease progression or unacceptable toxicity. Patients were premedicated with dexamethasone $20 \mathrm{mg}$, pheniramine maleate $45.5 \mathrm{mg}$, and famotidine $20 \mathrm{mg}, 30$ minutes before administration of paclitaxel. For practical reasons, capecitabine doses were rounded to the nearest dose that could be administered with a combination of 500-mg and 150-mg tablets of drug. Capecitabine was given approximately 12 hours apart and taken orally with water within 30 minutes after ingestion of food.

Capecitabine doses were interrupted in patients with grade 3 or 4 diarrhea or other non-hematologic toxicities and were reduced for subsequent cycles. The paclitaxel dose on day 8 was reduced to $75 \%$ in patients with an absolute neutrophil count (ANC) of 0.5 to $0.99 \times$ $10^{9} / \mathrm{L}$ and was omitted in patients with an ANC $\leq 0.5 \times$ $10^{9} / \mathrm{L}$; the dose was reduced to $50 \%$ for grade 3 nonhematologic toxicities and was omitted for grade 4 adverse events.

\section{Dose Modifications for Adverse Events}

Toxicity was evaluated before each treatment cycle according to the National Cancer Institute Common Toxicity Criteria (NCI CTC), version 3.0. To begin the next treatment cycle, each patient was required to have an absolute neutrophil count $(\mathrm{ANC}) \geq 1.5 \times 10^{9} / \mathrm{L}$, a platelet count $\geq 100 \times 10^{9} / \mathrm{L}$ and resolution of clinically significant non-hematological adverse events to grade 1 or 0 .

Treatment was continued at the same dose, without interruption or dose reduction, in patients experiencing 
grade 1 or other toxicities considered unlikely to become serious or life threatening (e.g., alopecia). For all other treatment-related adverse events of grade 2 or higher, a dose modification scheme was implemented. Dose reduction was not required following the first appearance of any grade 2 toxicity, although treatment was delayed until the toxicity had resolved to grades 01. Treatment with both agents was interrupted and the dose of both agents was reduced by $20 \%$ in patients who experienced a second occurrence of any grade 2 toxicity or at the first occurrence of any grade 3 toxicity. If patients experienced a third occurrence of any grade 2 toxicity or a second occurrence of any grade 3 toxicity, treatment was interrupted/delayed until the toxicity resolved to grades $0-1$ and the dose of both agents was further reduced by $20 \%$ of the previous dose. Treatment with both agents was discontinued if any grade 2 toxicity occurred for a fourth time or any grade 3 toxicity for a third time despite dose reduction. Treatment was discontinued if patients experienced a grade 4 nonhematologic toxicity. Paclitaxel was discontinued and capecitabine treatment was modified according to the scheme outlined above in patients with grade 3 peripheral neuropathy. The paclitaxel dose was reduced by $20 \%$ for patients who developed grade 4 neutropenia for more than 5 days or neutropenic fever.

\section{Statistical Analysis}

The primary objective of this study was to evaluate the response rate of paclitaxel plus capecitabine as secondline therapy in patients with metastatic or recurrent esophageal cancer. With the regard to the definition of therapy-line, the surgery and radiotherapy was not counted as therapy-line, only number of palliative chemotherapy was counted.

The Simon's two-stage optimal design was used for determining the total number of patients required for this phase II study. We set an overall response rate of $30 \%$ as the target activity level and $10 \%$ as the lowest overall response rate of interest. Our study was designed to have $90 \%$ statistical power with a $5 \%$ Type I error. With this design, 18 patients were enrolled at the first stage. If there were 2 or fewer responses out of the initial 18 patients, the study would conclude that the anticipated response rate is less than $10 \%$ and terminate. Otherwise, accrual continued to a total of 35 assessable patients. At the second stage, at least 7 objective responses among 35 patients were required for this regimen to be regarded as worthy of further investigation. Considering $10 \%$ follow up loss, 39 eligible patients would be enrolled. At the first stage, we observed a remarkably high response rate of $71 \%$ (5 partial responses among 7 patients). The protocol was therefore amended to estimate the response rate in patients with metastatic or recurrent esophageal cancer not only in the second-line setting, but also in the first-line setting. The response rate of the treatment was calculated as the ratio of the number of complete and partial responders to the total number of evaluable patients. A 95\% confidence interval for the response rate was computed based on the binomial distribution function. Toxicity profile was assessed as the ratio of the number of occurrence to the total number of evaluable patients. The secondary objectives included time to progression and overall survival, which was estimated by the KaplanMeier method. Overall survival time was calculated from the first day of treatment to death or the last day of follow-up. Progression-free survival time was calculated from the first day of treatment to the date that disease progression or death from any cause was reported.

\section{Results}

\section{Patient Characteristics}

Between February 2006 and February 2009, 32 patients with metastatic or recurrent esophageal cancer were enrolled at single institution. The baseline characteristics of the patients are summarized in Table 1. Twelve patients were chemotherapy-naïve. Twenty patients had received prior therapy including a platinum based regimen.

The median age was 60.5 years (range; 45 to 76 years) and all patients were male. $97 \%$ of patients had an ECOG performance status of $0-1$. Ten patients (31.3\%) had undergone surgery. All patients were assessable for efficacy and safety analyses.

\section{Treatment Exposure}

The median number of cycles of PACE administered to patients was five for all patients. Reasons for treatment discontinuation were as follows; 27 patients discontinued therapy for disease progression, 2 patients for toxicity, 2 patients for non-compliance, and one patient continues treatment at the time of final analysis. The relative dose intensity of paclitaxel and capecitabine was $88.2 \%$ and $86.5 \%$, respectively. The dose modifications were performed in only 11 (6.1\%) of 180 cycles administered to all patients.

\section{Efficacy}

An overall response rate for the PACE regimen of $56.3 \%$ (95\% CI, 39.0 to 73.4 ) was observed and the disease control rate was $75.0 \%$ (Table 2). Three patients achieved complete response (CR) and fifteen patients achieved partial response (PR). Among twelve patients receiving first-line treatment, two patients achieved CR and seven patients achieved $\mathrm{PR}$, giving an overall response rate of $75 \%$ (95\% CI, 50.5 to 99.5 ). Among twenty patients receiving second-line treatment, one patient achieved 
Table 1 Patient baseline characteristics

\begin{tabular}{|c|c|c|c|c|c|c|c|}
\hline \multicolumn{2}{|c|}{ Characteristics } & \multicolumn{2}{|c|}{ First-line } & \multicolumn{2}{|c|}{ Second-line } & \multirow[t]{2}{*}{ All patients } & \multirow[t]{2}{*}{ (\%) } \\
\hline & & No & (\%) & No & (\%) & & \\
\hline \multirow[t]{2}{*}{ Sex } & Male & 12 & (100) & 20 & $(100)$ & 32 & $(100)$ \\
\hline & Female & 0 & (0) & 0 & (0) & 0 & $(0.0)$ \\
\hline Age, median & & 58 & $(45-70)$ & 66 & $(54-76)$ & $60.5(45 \sim 76)$ & \\
\hline \multirow[t]{3}{*}{ ECOG PS } & 0 & 3 & $(25)$ & 6 & (30) & 9 & $(28.1)$ \\
\hline & 1 & 9 & (75) & 13 & $(65)$ & 22 & $(68.8)$ \\
\hline & 2 & 0 & $(0)$ & 1 & (5) & 1 & (3.1) \\
\hline Histology & Squamous & 12 & $(100)$ & 20 & $(100)$ & 32 & $(100)$ \\
\hline \multirow[t]{2}{*}{ Smoking history } & Never & 0 & (0) & 2 & (10) & 2 & (6.3) \\
\hline & Ever & 12 & $(100)$ & 18 & $(90)$ & 30 & $(93.7)$ \\
\hline \multirow[t]{4}{*}{ Prior therapy } & None & 6 & (50) & N/A & & 6 & \\
\hline & Surgery & 6 & (50) & 4 & $(20)$ & 10 & \\
\hline & Radiation & 0 & (0) & 2 & (10) & 2 & \\
\hline & Chemotherapy & N/A & & 20 & $(100)$ & 20 & \\
\hline \multirow[t]{3}{*}{ No.of metastatic sites } & 1 & 3 & $(25.0)$ & 5 & $(25)$ & 8 & $(25.0$ \\
\hline & 2 & 3 & $(25.0)$ & 10 & $(50)$ & 13 & $(40.6)$ \\
\hline & 3 & 1 & (8.3) & 4 & $(20)$ & 5 & $(15.6)$ \\
\hline Locoregional & & 5 & $(41.7)$ & 1 & (5) & 6 & $(18.8$ \\
\hline Metastatic & & 7 & $(58.3)$ & 19 & (95) & 26 & $(81.3)$ \\
\hline Liver & & 3 & $(25.0)$ & 13 & $(65)$ & 16 & $(50.0)$ \\
\hline Lung & & 7 & $(58.3)$ & 19 & (95) & 26 & $(81.3)$ \\
\hline Bone & & 2 & $(16.7)$ & 5 & $(25)$ & 7 & $(21.9)$ \\
\hline
\end{tabular}

Abbreviations: ECOG PS, Eastern Cooperative Oncology Group performance status; N/A, Not applicable.

$\mathrm{CR}$ and eight patients achieved PR. The response rate of second-line PACE was 45\% (95\% CI, 23.2 to 66.8 ). Among twenty patients treated with second-line therapy, six patients $(46.2 \%)$ who had a treatment free-interval of $<3$ months between their last chemotherapy and PACE showed an objective response, which reflects the clinical efficacy in patients whose tumors progress more rapidly (Table 3). All twenty patients treated in the second-line received platinum-based chemotherapy in the first-line setting. With respect to prior chemotherapy received for patients treated in the second-line, two patients out of three treated with prior 5-FU/cisplatin and one patient out of six treated with docetaxel/cisplatin achieved partial responses to PACE. The clinical efficacy of PACE seems to be more slightly lower in patients previously

Table 2 Tumor response rate and survival according to therapy line

\begin{tabular}{lllllll}
\hline Efficacy endpoints & \multicolumn{2}{l}{$\mathbf{1}^{\text {st }}$ line } \\
& \multicolumn{2}{l}{$\mathbf{n}=\mathbf{1 2})$} & \multicolumn{2}{l}{$\begin{array}{l}\mathbf{2}^{\text {nd }} \text { line } \\
(\mathbf{n}=\mathbf{2 0})\end{array}$} & \multicolumn{2}{l}{$\begin{array}{l}\text { Overall } \\
(\mathbf{n}=\mathbf{3 2})\end{array}$} \\
\cline { 2 - 7 } & No. & $\mathbf{( \% )}$ & No. & $\mathbf{( \% )}$ & No. & $(\%)$ \\
\hline Complete response & 2 & $(16.7)$ & 1 & $(5.0)$ & 3 & $(9.4)$ \\
Partial response & 7 & $(58.3)$ & 8 & $(40.0)$ & 15 & $(46.9)$ \\
Stable disease & 0 & $(0.0)$ & 6 & $(30.0)$ & 6 & $(18.7)$ \\
Progressive disease & 3 & $(25.0)$ & 5 & $(25.0)$ & 8 & $(25.0)$ \\
Overall response rate & 9 & $(75.0)$ & 9 & $(45.0)$ & 18 & $(56.3)^{*}$ \\
\hline
\end{tabular}

*(95\%Confidence Interval; 39.0-73.4). treated with docetaxel, which suggest that paclitaxel may have cross resistance to docetaxel (Table 4). However, any definitive conclusions can not be made due to small sample size.

Median progression-free survival was 5.2 months (95\% CI, 4.0 to 6.5 ) (Figure 1) and median overall survival (OS) was 11.7 months (95\% CI, 5.5 to 18.0 ) for all patients. The median OS was 14.3 months (95\% CI, 10.6 to 18.0 ) for patients receiving therapy as $1^{\text {st }}$ line and 8.4 months (95\% CI, 6.7 to 10.1 ) for those receiving as $2^{\text {nd }}$ line therapy (Figure 2).

\section{Safety and Tolerability}

All patients who received at least one cycle of study treatment were evaluated for toxicity $(n=32)$. The most

Table 3 Tumor response by treatment free-interval in patients treated as second-line

\begin{tabular}{|c|c|c|c|c|c|c|}
\hline \multirow[t]{3}{*}{ Tumor Response } & \multicolumn{6}{|c|}{ Treatment free-interval $(\mathrm{N}=20)$} \\
\hline & \multicolumn{2}{|c|}{$<3$ months } & \multicolumn{2}{|c|}{ 3-6 months } & \multicolumn{2}{|c|}{$>6$ months } \\
\hline & No. & (\%) & No. & (\%) & No. & (\%) \\
\hline Complete response & 1 & $(7.7)$ & 0 & $(0)$ & 0 & $(0)$ \\
\hline Partial response & 5 & $(38.5)$ & 1 & (33) & 3 & (75) \\
\hline Stable disease & 2 & $(15.4)$ & 2 & $(67)$ & 1 & $(25)$ \\
\hline Progressive disease & 5 & $(38.5)$ & 0 & $(0)$ & 0 & $(0)$ \\
\hline Total & 13 & $(100)$ & 3 & $(100)$ & 4 & $(100)$ \\
\hline
\end{tabular}


Table 4 Tumor response by prior regimen in patients treated as second-line

\begin{tabular}{lllll}
\hline \multirow{2}{*}{ Tumor Response } & \multicolumn{4}{l}{ Prior regimen $(\mathbf{N}=\mathbf{2 0})$} \\
\cline { 2 - 5 } & IP & FP & DP & NP \\
\hline Complete response & 0 & 0 & 0 & 1 \\
Partial response & 4 & 2 & 1 & 2 \\
Stable disease & 1 & 1 & 2 & 1 \\
Progressive disease & 2 & 0 & 3 & 0 \\
Total & 7 & 3 & 6 & 4 \\
\hline
\end{tabular}

Abbreviations: IP, Irinotecan/cisplatin; FP, 5-fluorouracil/cisplatin; DP,

docetaxel/cisplatin; NP, vinorelbine/cisplatin.

common treatment related adverse events are listed in Table 5. Hematologic toxicity was common, with seventeen $(53.1 \%)$ patients having grade 3-4 neutropenia and two $(6.3 \%)$ patients febrile neutropenia. The most common grade 3 to 4 non-hematologic adverse events were stomatitis $(\mathrm{n}=3)$, asthenia $(\mathrm{n}=2)$, hand-foot syndrome $(\mathrm{n}=1)$, and peripheral neuropathy $(\mathrm{n}=1)$. No grade 4 non-hematologic toxicity was observed and there was no treatment-related death.

\section{Discussion}

This prospective, phase II study provides important insights into the treatment of patients with esophageal squamous cell carcinoma. PACE showed promising efficacy, with an overall response rate of $75 \%$ as first-line, $45 \%$ as second-line and a median OS of 11.7 months. Treatment was well-tolerated and toxicity was manageable. Dysphagia is a common symptom in esophageal cancer, which may be cause of reduced number of eligible patients treated with capecitabine-based regimen. However, during study period, patients otherwise eligible

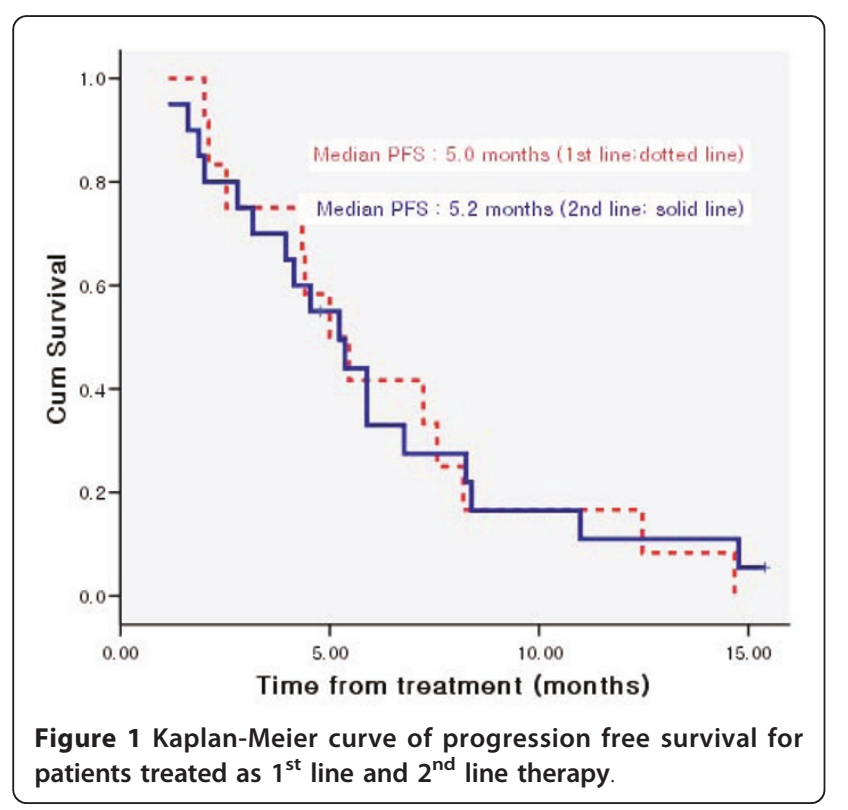

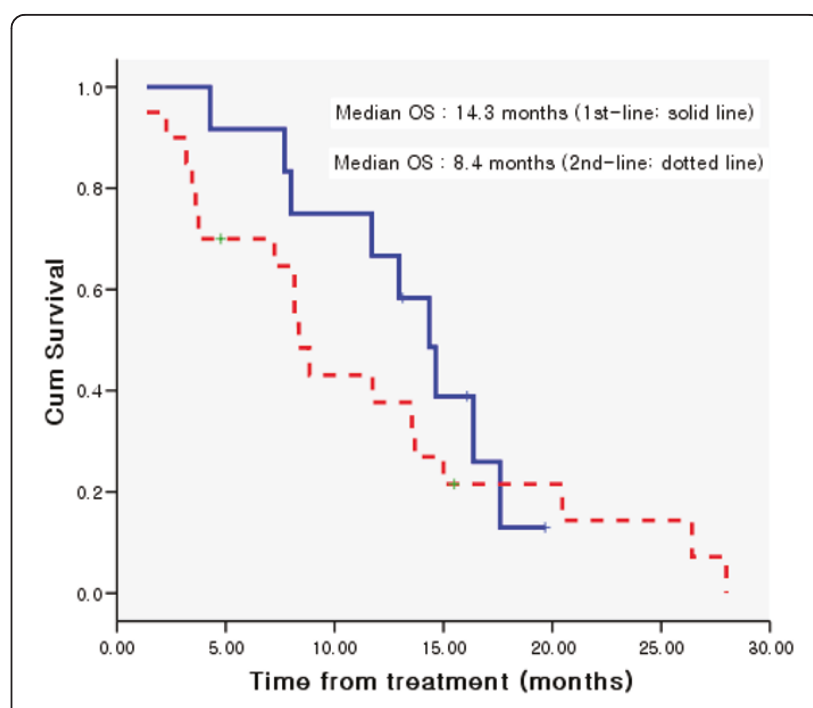

Figure 2 Kaplan-Meier curve of overall survival for patients treated as $1^{\text {st }}$ line and $2^{\text {nd }}$ line therapy.

who were excluded for dysphagia did not proceed the screening process and screening failure due to dysphagia was not observed. Oral administration of capecitabine is feasible and more convenient compared with infusional 5-FU in esophageal cancer.

Treatment of metastatic esophageal cancer still remains a serious challenge to medical oncologists. The most frequently used chemotherapy regimen is a combination of 5-fluorouracil and cisplatin, with response rates ranging from $20-45 \%$. Recently, new agents such as taxanes, vinorelbine, irinotecan, capecitabine, and oxaliplatin have been investigated as single agent or in combination in esophageal cancer [6,14-17]. The results of other phase II trials using various agents in esophageal cancer are summarized in Table 6. Although direct comparison is difficult across several trials due to different clinicopathologic characteristics of patients, our study shows at least comparable efficacy or better outcomes than those of other studies.

Several capecitabine-based regimens were evaluated in the first-line settings. Van Meerten et al [18] reported that capecitabine and oxaliplatin was an active regimen with a response rate of $39 \%$ and median OS of 8 months in the first-line. In that study, 45 of 51 patients $(88 \%)$ had a histologic diagnosis of adenocarcinoma, whereas all patients in our study had squamous cell histology. Another study demonstrated the efficacy of oxaliplatin and capecitabine in patients with esophageal squamous cell carcinoma (ESCC), with a response rate of $43.8 \%$ and a median OS of 10 months [19]. Although it is known that there are biological differences between esophageal adenocarcinoma and squamous cell cancer, clinical efficacy of capecitabine and oxaliplatin is not 
Table 5 Hematologic and non-hematologic toxicity (NCl-CTC version 3.0)

\begin{tabular}{|c|c|c|c|c|c|c|c|c|c|c|c|}
\hline & \multirow[t]{3}{*}{ Toxicity } & \multicolumn{10}{|c|}{ NCI-CTC Grade $(n=32)$} \\
\hline & & \multicolumn{2}{|c|}{0} & \multicolumn{2}{|c|}{1} & \multicolumn{2}{|c|}{2} & \multicolumn{2}{|c|}{3} & \multicolumn{2}{|c|}{4} \\
\hline & & No. & (\%) & No. & $(\%)$ & No. & (\%) & No. & $(\%)$ & No. & (\%) \\
\hline \multicolumn{12}{|l|}{ Hematologic } \\
\hline & Leukocytopenia & 4 & $(12.5)$ & 9 & $(28.1)$ & 11 & $(34.4)$ & 8 & $(25.0)$ & 0 & $(0.0)$ \\
\hline & Neutropenia & 5 & $(15.6)$ & 3 & $(9.4)$ & 7 & (21.9) & 10 & $(31.3)$ & 7 & $(21.9)$ \\
\hline & Anemia & 1 & (3.1) & 12 & $(37.5)$ & 17 & $(53.1)$ & 2 & $(6.3)$ & 0 & $(0.0)$ \\
\hline & Thrombocytopenia & 28 & $(87.5)$ & 4 & $(12.5)$ & 0 & $(0.0)$ & 0 & $(0.0)$ & 0 & $(0.0)$ \\
\hline \multicolumn{12}{|c|}{ Non-hematologic } \\
\hline Neurology & Neuropathy & 18 & $(56.3)$ & 8 & $(25.0)$ & 5 & (15.6) & 1 & (3.1) & 0 & $(0.0)$ \\
\hline \multirow[t]{5}{*}{ Gl } & Stomatitis & 13 & $(40.6)$ & 12 & $(37.5)$ & 4 & $(12.5)$ & 3 & (9.4) & 0 & $(0.0)$ \\
\hline & Anorexia & 10 & (31.3) & 17 & $(53.1)$ & 5 & (15.6) & 0 & $(0.0)$ & 0 & $(0.0)$ \\
\hline & Nausea/Nomiting & 16 & $(50.0)$ & 16 & $(50.0)$ & 0 & $(0.0)$ & 0 & $(0.0)$ & 0 & $(0.0)$ \\
\hline & Constipation & 23 & $(71.9)$ & 6 & $(18.8)$ & 3 & $(9.4)$ & 0 & $(0.0)$ & 0 & $(0.0)$ \\
\hline & Diarrhea & 24 & $(75.0)$ & 7 & $(21.9)$ & 1 & $(3.1)$ & 0 & $(0.0$ & 0 & $(0.0)$ \\
\hline \multirow[t]{3}{*}{ Hepatic } & AST $\uparrow$ & 27 & $(84.4)$ & 4 & $(12.5)$ & 1 & $(3.1)$ & 0 & $(0.0)$ & 0 & $(0.0)$ \\
\hline & $\mathrm{ALT} \uparrow$ & 29 & (90.6) & 3 & (9.4) & 0 & $(0.0)$ & 0 & $(0.0)$ & 0 & $(0.0)$ \\
\hline & Bilirubin $\uparrow$ & 25 & $(78.1)$ & 6 & $(18.8)$ & 1 & $(3.1)$ & 0 & $(0.0)$ & 0 & $(0.0)$ \\
\hline Renal & Creatinine $\uparrow$ & 23 & (71.9) & 8 & $(25.0)$ & 1 & (3.1) & 0 & $(0.0)$ & 0 & $(0.0)$ \\
\hline \multirow[t]{6}{*}{ Dermatology } & Alopecia & 5 & $(15.6)$ & 16 & $(50.0)$ & 11 & $(34.4)$ & 0 & $(0.0)$ & 0 & $(0.0)$ \\
\hline & Rash & 25 & $(78.1)$ & 5 & $(15.6)$ & 2 & $(6.3)$ & 0 & $(0.0)$ & 0 & $(0.0)$ \\
\hline & Itching & 27 & $(84.4)$ & 5 & $(15.6)$ & 0 & $(0.0)$ & 0 & $(0.0)$ & 0 & $(0.0)$ \\
\hline & Hyperpigmentation & 20 & $(62.5)$ & 10 & (31.3) & 2 & $(6.3)$ & 0 & $(0.0)$ & 0 & $(0.0)$ \\
\hline & Nail change & 24 & $(75.0)$ & 3 & (9.4) & 4 & $(12.5)$ & 1 & (3.1) & 0 & $(0.0)$ \\
\hline & Hand-foot syndrome & 18 & $(56.3)$ & 9 & $(28.1)$ & 4 & $(12.5)$ & 1 & (3.1) & 0 & $(0.0)$ \\
\hline \multirow[t]{4}{*}{ Others } & Asthenia & 8 & $(25.0)$ & 16 & $(50.0)$ & 6 & $(18.8)$ & 2 & (6.3) & 0 & $(0.0)$ \\
\hline & Myalgia & 23 & $(71.9)$ & 8 & $(25.0)$ & 1 & $(3.1)$ & 0 & $(0.0)$ & 0 & $(0.0)$ \\
\hline & Febrile neutropenia & 30 & $(93.8)$ & 0 & $(0.0)$ & 0 & $(0.0)$ & 2 & $(6.3)$ & 0 & $(0.0)$ \\
\hline & Pneumonitis & 30 & $(93.8)$ & 1 & (3.1) & 0 & $(0.0)$ & 1 & (3.1) & 0 & $(0.0)$ \\
\hline
\end{tabular}

Table 6 Results of phase II trials in esophageal cancer

\begin{tabular}{|c|c|c|c|c|c|c|}
\hline Author & Regimen & Histology & Therapy line & Response rate (\%) & TTP/PFS & OS \\
\hline Lee [20] & $\begin{array}{l}\text { XP }\left(X: 2,500 \mathrm{mg} / \mathrm{m}^{2} \mathrm{D} 1-14\right. \\
\text { CDDP:60 mg/m } ; \mathrm{m} 1)\end{array}$ & $\begin{array}{l}\text { SCC } \\
(n=45)\end{array}$ & $\begin{array}{l}1^{\text {st }} \text { line } \\
(n=45)\end{array}$ & $57.8 \%$ & $4.7 \mathrm{mon}$ & $11.2 \mathrm{mon}$ \\
\hline Van Meerten [18] & $\begin{array}{l}\text { XELOX } \\
\text { (X:2,000 mg/m² D1-14 } \\
\text { O:130 mg/m²; D1) }\end{array}$ & $\begin{array}{l}\text { ADC }(n=45) \\
\text { SCC }(n=4) \\
\text { Undiff. }(n=2)\end{array}$ & $\begin{array}{l}1^{\text {st }} \text { line } \\
(n=51)\end{array}$ & $39 \%$ & NR & 8 mon \\
\hline MB Polee [28] & $\begin{array}{l}\text { Paclitaxel:180 mg/m²;D1 } \\
\text { CDDP:60 mg/m²; D1 }\end{array}$ & $\begin{array}{l}\text { ADC }(n=31) \\
\text { SCC }(n=16) \\
\text { Undiff }(n=4)\end{array}$ & $\begin{array}{l}1^{\text {st }} \text { line } \\
(n=51)\end{array}$ & $\begin{array}{l}\operatorname{ADC}(39 \%) \\
\operatorname{SCC}(44 \%)\end{array}$ & NR & 9 mon \\
\hline Zhang [29] & $\begin{array}{l}\text { Paclitaxel:175 mg/m } \mathrm{m}^{2} \text { on D1 } \\
\text { CDDP:75 mg/m² (D1) }\end{array}$ & $\begin{array}{l}\text { SCC } \\
(n=35)\end{array}$ & $\begin{array}{l}1^{\text {st }} \text { line } \\
(n=35)\end{array}$ & $48.6 \%$ & 7 mon & 13 mon \\
\hline S.Lorenzen [21] & $\begin{array}{l}\text { DX } \\
\left(X: 2,000 \mathrm{mg} / \mathrm{m}^{2} \mathrm{D} 1-14\right. \\
\text { D:75 mg/m²; D1) }\end{array}$ & $\begin{array}{l}\operatorname{ADC}(n=7) \\
\operatorname{SCC}(n=17)\end{array}$ & $\begin{array}{l}1^{\text {st }}(n=16) \\
2^{\text {nd }}(n=8)\end{array}$ & $\begin{array}{l}1^{\text {st }}(56 \%) \\
2^{\text {nd }}(25 \%) \\
\text { Overall }=46 \%\end{array}$ & 6.1 mon & $\begin{array}{l}1^{\text {st }}(15.8) \\
2^{\text {nd }}(6.2)\end{array}$ \\
\hline S.Lorenzen [26] & $\begin{array}{l}F P+\text { Cetuximab vs } \\
F P\end{array}$ & $\operatorname{SCC}(n=62)$ & $\begin{array}{l}1^{\text {st }} \text { line } \\
(n=62)\end{array}$ & $\begin{array}{l}\text { FP+ Cetuximab (19\%) } \\
\text { FP (13\%) }\end{array}$ & $\begin{array}{l}5.9 \mathrm{mon} \\
3.6 \mathrm{mon}\end{array}$ & $\begin{array}{l}9.5 \mathrm{mon} \\
5.5 \mathrm{mon}\end{array}$ \\
\hline Current Study & $\begin{array}{l}\text { Xeloda } 1,800 \mathrm{mg} / \mathrm{m}^{2} \mathrm{D} 1-14 \\
\text { Paclitaxel:80 mg/m } \mathrm{m}^{2} \text { on D1, D8 }\end{array}$ & $\operatorname{SCC}(n=32)$ & $\begin{array}{l}1^{\text {st }}(n=12) \\
2^{\text {nd }}(n=20)\end{array}$ & $\begin{array}{l}1^{\text {st }}(75 \%) \\
2^{\text {nd }}(45 \%) \\
\text { Overall }=53.6 \%\end{array}$ & $\begin{array}{l}5.23 \text { mon } \\
4.54 \text { mon }\end{array}$ & $\begin{array}{l}14.3 \text { mon } \\
8.4 \text { mon }\end{array}$ \\
\hline
\end{tabular}

Abbreviations: XP, capecitabine/cisplatin; XELOX, capecitabine/oxaliplatin; DX, docetaxel/capecitabine; FP, 5-fluorouracil/cisplatin; SCC, squamous cell carcinoma; $A D C$, adenocarcinoma; Undiff, undifferentiated carcinoma; TTP, time to progression; PFS, progression-free survival; OS, overall survival; NR, not reported. 
different between adenocarcinoma and squamous cell carcinoma of the esophagus. Lee et al [20] also reported the results of cisplatin and capecitabine (XP) in ESCC. The response rate was $57.8 \%$ and median OS was 11.2 months. The authors concluded that the XP regimen was a promising combination chemotherapy in metastatic esophageal squamous cell carcinoma with a tolerable toxicity profile. Another docetaxel/capecitabine trial reported a response rate of $46 \%$ and median survival of 15.8 months [21]. However the incidence of hand-foot syndrome (HFS) and diarrhea was higher than that of our study, which can be explained by the lower dose of capecitabine (900 mg/m ${ }^{2}$ twice daily) in our study. Another explanation for lower rate of HFS in our study is that the risk factors for HFS have been reported to include use of docetaxel chemotherapy and ethnic differences may also contribute to the occurrence of HFS [22]. Randomized phase II study of weekly docetaxel (30 $\left.\mathrm{mg} / \mathrm{m}^{2}\right)$ on days 1 and 8 and capecitabine $\left(1600 \mathrm{mg} / \mathrm{m}^{2}\right.$ per day) on days 1-14 showed a response rate of $26 \%$, median PFS of 4.6 months, and OS of 10.1 months in patients with esophagogastric cancer. However, in this study, only $36 \%$ of patients were esophageal cancers and $16 \%$ of patients had squamous cell carcinoma. The confirmed response rate was $26 \%$, which was lower than that of our study, in which only unconfirmed response rate was reported. The more than grade 3 HFS was observed in $5 \%$ of patients treated with docetaxel and capecitabine [23].

Paclitaxel-based regimens were evaluated in patients with esophageal cancer. The result of a phase II trial of paclitaxel and nedaplatin as first line chemotherapy for advanced esophageal cancer was reported, with a response rate of $41.7 \%$, median time to progression of 6.1 months and median overall survival of 11.5 months [24]. In this study, 46 of 48 patients had squamous cell histology and 2 patients had adenocarcinomas. Another study using paclitaxel and nedaplatin as first line therapy showed that the overall response rate was $43.6 \%$, median progression-free survival and median overall survival was 6.1 and 10.3 months, respectively [25]. Among 39 enrolled patients, 36 (92.3\%) had squamous cell carcinoma. Similar to metastatic disease, in unresectable locally advanced esophageal cancer (squamous/adenocarcinoma; 36/14), definitive concurrent chemoradiation with weekly paclitaxel and carboplatin also showed promising efficacy with OS of 17 months and median time to local progression of 14 months, which demonstrated high clinical activity of paclitaxel-based regimen.

However, median overall survival rarely exceeds 12 months despite the improvement of chemotherapy regimens and supportive care in metastatic esophageal squamous cell carcinoma. There are several strategies to improve the overall survival of metastatic solid tumors, such as adding another cytotoxic agent to doublet regimen, thus using triplet therapies and adding molecular targeted agents to cytotoxic chemotherapy. As shown in many solid tumors, several clinical trials with triplet chemotherapy (taxane, platinum and 5-FU) demonstrated no superiority to historical doublet chemotherapy regimens in metastatic esophageal cancer,[2] although no direct comparison is possible across the trials. Regarding molecular targeted agents, a randomized phase II study comparing the epidermal growth factor receptor (EGFR) inhibitor, cetuximab in combination with 5-FU and cisplatin (FC), with FC alone was conducted to evaluate the efficacy and safety in first-line metastatic squamous cell carcinoma of the esophagus [26]. The median PFS (5.9 versus 3.6 months) and the median OS (9.5 versus 5.5 months) both favored the cetuximab plus FC combination, but the median OS of 9.5 months was disappointing despite the addition of cetuximab to chemotherapy, considering the median OS ranging between 8 and 15 months reported in several phase II trials with chemotherapy alone [6,20,21,27].

Maintaining quality of life (QOL) and symptom relief are important factors in the management of patients with metastatic solid tumors. In this study, we did not evaluate QOL, including dysphagia, during study period, but the toxicities were generally well-tolerated for most patients. The most common reason for treatment discontinuation was disease progression, whereas only two patients stopped therapy due to toxicity.

Compared with other studies, the observed response rate, although not confirmed at least 4 weeks after initial response evaluation, was higher than our expectations at the time of study design despite administering treatment as second-line therapy, so the patients who were not previously treated with any chemotherapy were also included in this study. However, although change of patients population was another weak point of our study, at the first stage, we observed a remarkably high response rate of $71 \%$ ( 5 partial responses among 7 patients) and considering that the incidence of esophageal cancer is relatively low and patients recruitment was slow, we enrolled the patients in the first-line setting. With regard to protocol amendment, we did not consider statistical correction.

The median OS was 14.3 months for patients receiving therapy as $1^{\text {st }}$-line and 8.4 months for those receiving as $2^{\text {nd }}$-line therapy. Although the small sample size of patients treated as $1^{\text {st }}$-line makes it difficult to draw definitive conclusions, this regimen deserves further evaluation as front-line treatment for esophageal cancer considering the high clinical activity observed in our study. 


\section{Conclusions}

Weekly paclitaxel and capecitabine treatment as firstand second-line therapy is highly active and well-tolerated in patients with advanced esophageal squamous cell carcinoma. Non-platinum based doublet chemotherapy showed significant clinical benefit in our study, and further studies using non-platinum-based chemotherapy are warranted for the treatment of esophageal cancer. Ultimately, randomized clinical trials are needed to determine the efficacy and safety of paclitaxel and capecitabine for esophageal cancer patients.

\section{Conflict of interest disclosures}

The authors declare that they have no competing interests.

\section{Acknowledgements}

This study was supported in part by grants from the National Cancer Center of Korea (05101403).

\section{Author details \\ ${ }^{1}$ Lung Cancer Branch, National Cancer Center, Goyang, Republic of Korea. ${ }^{2}$ Cancer Biostatistics Branch, National Cancer Center, Goyang, Republic of Korea.}

\section{Authors' contributions}

HTK: Study design, interpretation of data and preparation of the article for publication.

TY: Collection of data, interpretation of data and writing the manuscript. HLC: Collection of data. HYK: Implementation of the radiologic response. $\mathrm{BHN}$ : Performing the statistical analysis. JYH, JSL: Collection of data and interpretation of data.

All authors read and approved the final manuscript.

Received: 6 September 2010 Accepted: 2 September 2011

Published: 2 September 2011

\section{References}

1. Enzinger PC, Ilson DH, Kelsen DP: Chemotherapy in esophageal cancer. Semin Oncol 1999, 26(5 Suppl 15):12-20.

2. Ilson DH, Ajani J, Bhalla K, Forastiere A, Huang Y, Patel P, Martin L, Donegan J, Pazdur R, Reed C, et al: Phase II trial of paclitaxel, fluorouracil, and cisplatin in patients with advanced carcinoma of the esophagus. J Clin Oncol 1998, 16(5):1826-1834.

3. Spiridonidis CH, Laufman LR, Jones JJ, Gray DJ, Cho CC, Young DC: A phase II evaluation of high dose cisplatin and etoposide in patients with advanced esophageal adenocarcinoma. Cancer 1996, 78(10):2070-2077.

4. Ohwada S, Nakamura S, Izumi M, Kawashima Y, Ogawa T, Kobayashi I, Hosomura Y, Joshita T, Lino Y, Morishita Y: Neoadjuvant chemotherapy with etoposide, leucovorin, 5-fluorouracil and cisplatin for advanced esophageal squamous cell carcinoma. Jpn J Clin Oncol 1995, 25(3):79-85.

5. Hayashi K, Ando N, Watanabe H, Ide H, Nagai K, Aoyama N, Takiyama W, Ishida K, Isono K, Makuuchi $\mathrm{H}$, et al: Phase II evaluation of protracted infusion of cisplatin and 5-fluorouracil in advanced squamous cell carcinoma of the esophagus: a Japan Esophageal Oncology Group (JEOG) Trial (JCOG9407). Jpn J Clin Oncol 2001, 31(9):419-423.

6. Ilson DH, Saltz L, Enzinger P, Huang Y, Kornblith A, Gollub M, O'Reilly E, Schwartz G, DeGroff J, Gonzalez G, et al: Phase II trial of weekly irinotecan plus cisplatin in advanced esophageal cancer. J Clin Oncol 1999 17(10):3270-3275.

7. Nakadate M, Yamazaki K, Konishi J, Kinoshita I, Sukoh N, Harada M, Akie K, Ogura S, Ishida T, Munakata M, et al: Phase II study of carboplatin and weekly paclitaxel in advanced non-small cell lung cancer. Anticancer Res 2006, 26(5B):3767-3772.
8. Socinski MA, Ivanova A, Bakri K, Wall J, Baggstrom MQ, Hensing TA, Mears A, Tynan M, Beaumont J, Peterman AH, et al: A randomized phase II trial comparing every 3-weeks carboplatin/paclitaxel with every 3-weeks carboplatin and weekly paclitaxel in advanced non-small cell lung cancer. Ann Oncol 2006, 17(1):104-109.

9. Schuller J, Cassidy J, Dumont E, Roos B, Durston S, Banken L, Utoh M, Mori K, Weidekamm E, Reigner B: Preferential activation of capecitabine in tumor following oral administration to colorectal cancer patients. Cancer Chemother Pharmacol 2000, 45(4):291-297.

10. Sawada N, Ishikawa T, Fukase Y, Nishida M, Yoshikubo T, Ishitsuka H: Induction of thymidine phosphorylase activity and enhancement of capecitabine efficacy by taxol/taxotere in human cancer xenografts. Clin Cancer Res 1998, 4(4):1013-1019.

11. Han JY, Lee DH, Kim HY, Hong EK, Yoon SM, Chun JH, Lee HG, Lee SY, Shin EH, Lee JS: A phase II study of weekly docetaxel plus capecitabine for patients with advanced nonsmall cell lung carcinoma. Cancer 2003, 98(9):1918-1924.

12. O'Shaughnessy J, Miles D, Vukelja S, Moiseyenko V, Ayoub JP, Cervantes G, Fumoleau P, Jones S, Lui WY, Mauriac L, et al: Superior survival with capecitabine plus docetaxel combination therapy in anthracyclinepretreated patients with advanced breast cancer: phase III trial results. J Clin Oncol 2002, 20(12):2812-2823.

13. Park YH, Ryoo BY, Choi SJ, Kim HT: A phase II study of capecitabine and docetaxel combination chemotherapy in patients with advanced gastric cancer. Br J Cancer 2004, 90(7):1329-1333.

14. Burkart C, Bokemeyer C, Klump B, Pereira P, Teichmann R, Hartmann JT: A phase II trial of weekly irinotecan in cisplatin-refractory esophageal cancer. Anticancer Res 2007, 27(4C):2845-2848.

15. Ilson DH: Phase II trial of weekly irinotecan/cisplatin in advanced esophageal cancer. Oncology (Williston Park) 2004, 18(14 Suppl 14):22-25.

16. Kim DW, Blanke CD, Wu H, Shyr Y, Berlin J, Beauchamp RD, Chakravarthy B: Phase II study of preoperative paclitaxel/cisplatin with radiotherapy in locally advanced esophageal cancer. Int J Radiat Oncol Biol Phys 2007, 67(2):397-404

17. Henry LR, Goldberg M, Scott W, Konski A, Meropol NJ, Freedman G, Weiner LM, Watts P, Beard M, McLaughlin S, et al: Induction cisplatin and paclitaxel followed by combination chemoradiotherapy with 5fluorouracil, cisplatin, and paclitaxel before resection in localized esophageal cancer: a phase II report. Ann Surg Oncol 2006, 13(2):214-220

18. van Meerten E, Eskens FA, van Gameren EC, Doorn L, van der Gaast A: First-line treatment with oxaliplatin and capecitabine in patients with advanced or metastatic oesophageal cancer: a phase II study. Br J Cancer 2007, 96(9):1348-1352.

19. Qin TJ, An GL, Zhao XH, Tian F, Li XH, Lian JW, Pan BR, Gu SZ: Combined treatment of oxaliplatin and capecitabine in patients with metastatic esophageal squamous cell cancer. World J Gastroenterol 2009, 15(7):871-876.

20. Lee J, Im YH, Cho EY, Hong YS, Lee HR, Kim HS, Kim MJ, Kim K, Kang WK, Park $K$, et al: A phase II study of capecitabine and cisplatin (XP) as firstline chemotherapy in patients with advanced esophageal squamous cell carcinoma. Cancer Chemother Pharmacol 2008, 62(1):77-84.

21. Lorenzen S, Duyster J, Lersch C, von Delius S, Hennig M, Bredenkamp R, Peschel C, Lordick F: Capecitabine plus docetaxel every 3 weeks in firstand second-line metastatic oesophageal cancer: final results of a phase II trial. Br J Cancer 2005, 92(12):2129-2133.

22. Kang YK, Lee SS, Yoon DH, Lee SY, Chun YJ, Kim MS, Ryu MH, Chang HM, Lee $J$, Kim TW: Pyridoxine is not effective to prevent hand-foot syndrome associated with capecitabine therapy: results of a randomized, double-blind, placebo-controlled study. J Clin Oncol 2010, 28(24):3824-3829.

23. Tebbutt NC, Cummins MM, Sourjina T, Strickland A, Van Hazel G, Ganju V, Gibbs D, Stockler M, Gebski V, Zalcberg J: Randomised, non-comparative phase II study of weekly docetaxel with cisplatin and 5-fluorouracil or with capecitabine in oesophagogastric cancer: the AGITG ATTAX trial. Br J Cancer 2010, 102(3):475-481.

24. Cao W, Xu C, Lou G, Jiang J, Zhao S, Geng M, Xi W, Li H, Jin Y: A Phase II Study of Paclitaxel and Nedaplatin as First-line Chemotherapy in Patients with Advanced Esophageal Cancer. Jpn J Clin Oncol 2009.

25. Gong Y, Ren L, Zhou L, Zhu J, Huang M, Zhou X, Wang J, Lu Y, Hou M, Wei $Y$ : Phase II evaluation of nedaplatin and paclitaxel in patients with 
metastatic esophageal carcinoma. Cancer Chemother Pharmacol 2009, 64(2):327-333.

26. Lorenzen S, Schuster T, Porschen R, Al-Batran SE, Hofheinz R, ThussPatience P, Moehler M, Grabowski P, Arnold D, Greten T, et al: Cetuximab plus cisplatin-5-fluorouracil versus cisplatin-5-fluorouracil alone in firstline metastatic squamous cell carcinoma of the esophagus: a randomized phase II study of the Arbeitsgemeinschaft Internistische Onkologie. Ann Oncol 2009, 20(10):1667-1673.

27. Petrasch S, Welt A, Reinacher A, Graeven U, Konig M, Schmiegel W: Chemotherapy with cisplatin and paclitaxel in patients with locally advanced, recurrent or metastatic oesophageal cancer. Br J Cancer 1998, 78(4):511-514

28. Polee MB, Eskens FA, van der Burg ME, Splinter TA, Siersema PD, Tilanus HW, Verweij J, Stoter G, van der Gaast A: Phase II study of bi-weekly administration of paclitaxel and cisplatin in patients with advanced oesophageal cancer. Br J Cancer 2002, 86(5):669-673.

29. Zhang X, Shen L, Li J, Li Y, Jin M: A phase II trial of paclitaxel and cisplatin in patients with advanced squamous-cell carcinoma of the esophagus. Am J Clin Oncol 2008, 31(1):29-33.

\section{Pre-publication history}

The pre-publication history for this paper can be accessed here: http://www.biomedcentral.com/1471-2407/11/385/prepub

\section{doi:10.1186/1471-2407-11-385}

Cite this article as: Yun et al:: Phase II study of weekly paclitaxel and capecitabine in patients with metastatic or recurrent esophageal squamous cell carcinoma. BMC Cancer 2011 11:385.

\section{Submit your next manuscript to BioMed Central and take full advantage of:}

- Convenient online submission

- Thorough peer review

- No space constraints or color figure charges

- Immediate publication on acceptance

- Inclusion in PubMed, CAS, Scopus and Google Scholar

- Research which is freely available for redistribution

Submit your manuscript at www.biomedcentral.com/submit 